\title{
THE EFFECT OF TECHNOLOGICAL BEHAVIOR TOWARDS THE ADOPTION OF EDUCATION INTEGRATED SYSTEM AMONG NEW INTAKE STUDENTS
}

\author{
Ayub Ilfandy Imran ${ }^{1}$ \\ Digital Public Relations Department, Faculty of Communication and Business, Telkom University \\ Email:ayub@gmail.com
}

Naskah diterima tanggal 20 Desember 2018, direvisi tanggal 10 Januari 2019, disetujui tanggal 30 Januari 2019

\begin{abstract}
Abstrak. Implementasi sistem teknologi pada anggota organisasi selalu menciptakan peluang besar serta tantangan yang intens. Pada pengaturan pendidikan, pengenalan sistem teknologi terintegrasi pada siswa yang baru masuk memberikan kemungkinan penerimaan dan resistensi. Penegakan Sistem Informasi Akademik Terpadu Universitas Telkom (iGracias) pada anggota institusinya telah menciptakan tantangan besar untuk mencapai adopsi, terutama di antara anggota baru. Secara khusus, penelitian ini bertujuan mengukur tingkat kesadaran, persepsi, dan sikap terhadap iGracias dan dampaknya pada adopsi aktual siswa. Didesain dengan pendekatan kuantitatif, penelitian ini berupaya menguji hipotesis yang dirumuskan dan untuk memvalidasi model baru berdasarkan respons dari 200 siswa yang baru masuk pada tahun akademik 2018 di Universitas Telkom. Hasil penelitian menunjukkan bahwa kesadaran dan persepsi siswa berhubungan positif dan signifikan dengan sikap mereka terhadap iGracias. Analisis juga menunjukkan hubungan positif dan signifikan antara sikap pada iGracias terhadap penerapannya. Selain itu, hasil menemukan bahwa sikap terhadap iGracias memiliki efek mediasi pada kesadaran dan persepsi pada teknologi. Akhirnya, penelitian ini juga berhasil memvalidasi model baru dan berpendapat relevansi praktisnya pada konteks organisasi yang sama.
\end{abstract}

Katakunci: Adopsi, Sistem Komputerisasi Terpadu, Perilaku Teknologi.

Abstract. The implementation of technological system on the members of organization has always create great opportunities as well as intense challenges. On educational settings, the introduction of integrated technology system on the newly intake students provides the possibility of both acceptance and resistance. The enforcement of Telkom University's Integrated Academic Information System (iGracias) on its institutional members has create great challenges to achieve its adoption, especially among its new members. Specifically, this study aims at measuring the level of awareness, perception, and attitude towards iGracias and its impact on the students' actual adoption. Designed with a quantitative approach, this research seeks to test the formulated hypotheses and to validate a new model based on the responses from 200 newly intake students of 2018 academic year at Telkom University. The results of the study indicate that students' awareness and perception are positively and significantly related to their attitude towards the iGracias. the analysis also point out a positive and significant relationship between attitude on iGracias towards its adoption. Furthermore, the results found that the attitude towards the iGracias has mediating effects on both awareness and perception on the technology. Finally, the study also manages to validate a new model and argues its practical relevance on the similar organizational context.

Keywords: Adoption, Computerized Integrated System, Technological Behavior. 


\section{INTRODUCTION}

The rapid technological advancement has significantly influence the way many organizations execute their work process as well their services. This situation has been seen at education institutions such as university. The work processes and services at higher learning institutions has much been forced to adapt to the latest technological advancement with the spirit of improving their quality of teaching and services, and therefore, maintain their competitive edge among similar type of institutions (Imran, 2016). One of the most common example of technological development within the academic based institutions is the creation of computerized and integrated educational technological system within the teaching and learning aspects. Such system has been created and rapidly developed in order to integrate the academic work processes to enhance the efficiency of academic related activities.

Telkom University, one of the digitally advanced private campus, has developed a very comprehensive system called iGracias to manage various activities of their institutional members. IGracias, abbreviated from Integrated Academic Information System, was developed in order to computerize and to digitalize numerous academic related activities to ensure its efficiency. With a Single Sign On (SSO) feature, iGracias provides a user friendly system which enables its users to perform various academic functions, such as, course registration, academic status, scheduling, communicating, and dissemination of news. The usage of iGracias has proven its benefits for both lecturers and students, hence optimize the efficiency of their academic performance.

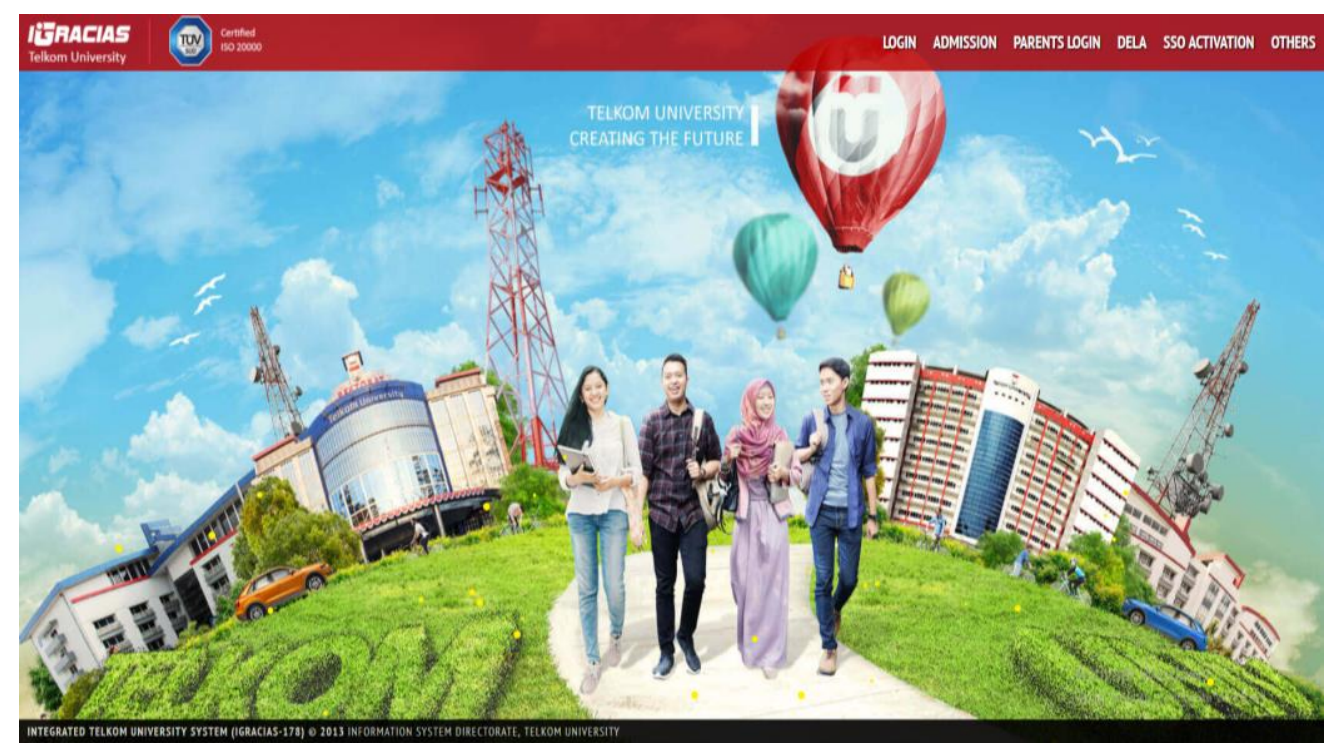

Figure 1: iGracias Login Page (Source: https://igracias.telkomuniversity.ac.id/) 
Since its initiation, Igracias has gone through numerous improvements and modifications along the years such as, inclusions of new features, layout designs, and addition of new dashboard. Despite its apparent functions and benefits, iGracias has also shown several technical and practical issues over the years. Users' complaints regarding its stability of access, ease of use, and missing features has created hindrances on its development. Such problems are felt even more by students who are still on the learning process or yet to use the system. Therefore, the most challenging aspects faced by the system developers is to maximize the acceptance and mastering of this application among the newly intake students in every academic year.

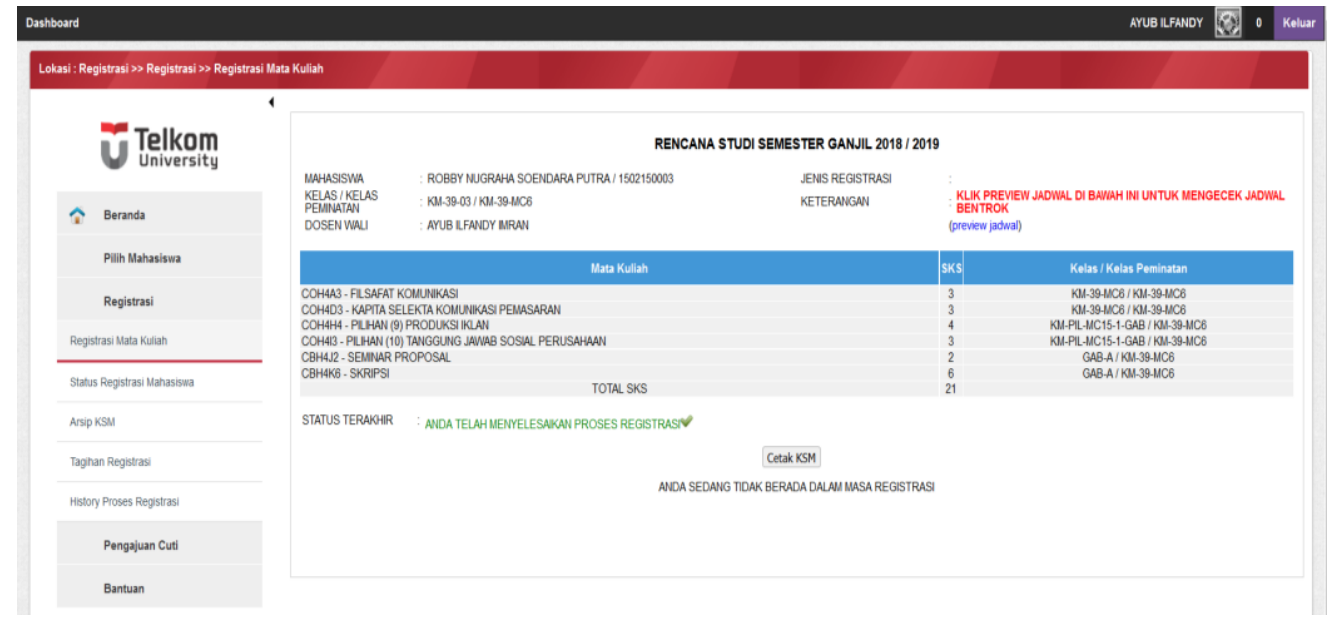

Figure 2: iGracias Internal Features (Source: https://igracias.telkomuniversity.ac.id/)

Considering the aforementioned backgrounds, therefore, this study was set to investigate the technological behavior of the newly intake students with the technological adoption as the actual output. Specifically, this study aims at measuring the level of awareness, perception, and attitude towards iGracias and its impact on the students' actual adoption. In addition, this study seek to propose and confirm a conceptual framework reflecting the objectives and findings of the study. For its theoretical approach this paper referred to the definitions and elaborations of the variables as its literature review which fundamentally based on two interrelated theories, namely, the original Technology Acceptance Model (TAM) which was introduced by Fred Davis in 1986 and the advanced Technology Acceptance Model (TAM2) which was introduced by Venkatesh and Davis in 2000 (Lai, 2017). The theoretical background of this research also resembles the implementation of Everett Rogers' Theory of Diffusion of Innovations (DIT) which was introduced in 1995 (Mun, Joyce, Jae, \& Janice, 2006).

Technological behavior is a set of behavioral aspects which an individual possesses pertaining to their awareness, perception, and attitude towards a technological existence which directly affects him/her. Awareness is defined as the process of realizing, knowing, and 
understanding either existing matters or occurring changes in the surroundings (Wojtecki \& Peters, 2000). Reed (2001) added that most individuals create awareness regarding the new technology before adopting it. He believed that exciting new technology advancement always trigger high level of awareness among younger potential adopters.

Kearns (2004), meanwhile, regarded perception as one of the most important dimension in communication technology adoption and defined it as the degree to which a person believes towards certain issues related to the technology. In addition, Jones and Johnson (2005) stated that individuals possess thoughts, perceptions, and personalities that affect the way they use the technology. They added that perception towards technology is based on how the technology benefits each individual. Attitude defined by Weick (1990) as the preference/likeability, feelings, approach and manner towards new things." According to Weick (1990), technology innovation is commonly interpreted differently by people, and therefore, every individual has different attitude towards the technology according to their own comfort and experience of using the technology. All of these aspects are believed to be directly connected to the level of technological adoption among its potential users.

With the aforementioned literature review and theoretical background this study therefore derived a technological conceptual framework (see Figure 1.3 below). The proposed research model suggests that awareness and perception on a new technology mediated by positive attitude will eventually create a relatively high rate of technological adoption. Additionally, this research model highlights the mediating effect of attitude on awareness and perception towards technological adoption.

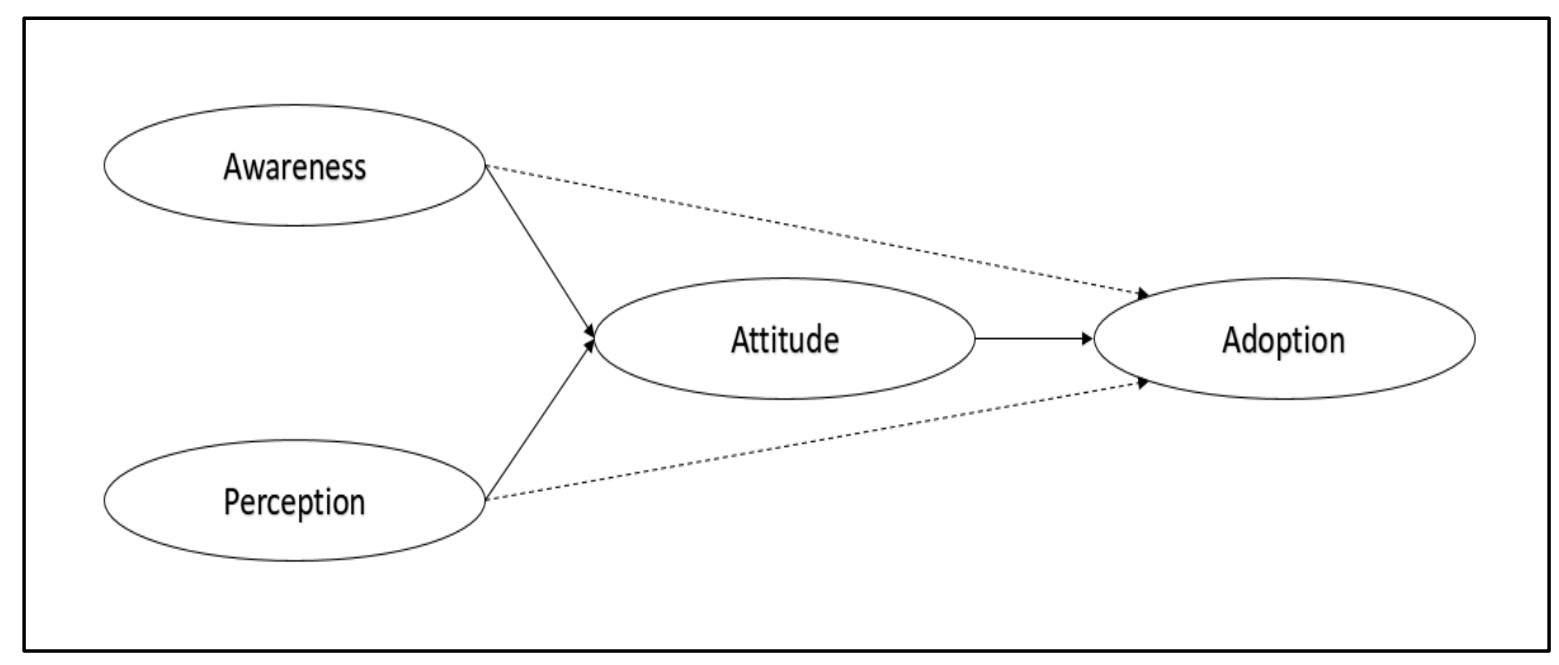

Figure 3: Proposed Research Model

Based on both literature review and proposed research model, the following research hypotheses are formulated: 
H1: Awareness and perception has direct and positive correlations with the attitude towards the technology.

H2: Attitude has a direct and positive correlation with the adoption of the technology.

H3: Attitude has mediating effects on awareness and perception towards the adoption of the technology.

\section{RESEARCH METHOD}

To fulfill the objective of the study, this research set up a quantitative research design in which a self-administered questionnaire was developed to measure the selected variables, namely, Awareness, Adoption, Attitude, and Adoption of the technology. Each variable was measured by 10 items, and each item was measured by a four Likert scale statement. The questionnaire was printed and distributed into the selected classes of new intake students. Students from the Faculty of Communication and Business were chosen as one of the faculty with the highest number of new intake students in each enrolling academic year at Telkom University. The data collection took about two months while students were still on their first semester and still on the process of learning and adjusting towards using the iGracias.

From a total of over 1200 students in 2018 batch, 214 were chosen and participated by answering the questionnaire. Using a stratified random sampling, the proportion was determined by the actual number of new students from three departments, namely, Communication Science (43\%), Business Administration (39\%), and Public Relations (16\%). Table 1 below shows the actual number of respondents.

Tabel 1

Stratification of the Respondents

\begin{tabular}{ccrr}
\hline Number & Department & Frequency & Percentage \\
\hline 1 & Communication Science & 93 & 43.5 \\
\hline 2 & Business Administration & 85 & 39.8 \\
\hline 3 & Public Relations & 36 & 16.8 \\
\hline & Total & $\mathbf{2 1 4}$ & $\mathbf{1 0 0 . 0}$ \\
\hline
\end{tabular}

Source: Data collection of the research

To test the formulated hypotheses, both descriptive and inferential statistics were used in this study. The descriptive statistics involved the elaboration of frequency, percentage, mean, and standard deviations. While the inferential statistics used factor analysis, correlation, regression, and coefficient determination. The results of the analyses will be reported in the next section. 


\section{RESULT AND DISCUSSION}

The first part of the findings presents the results of the descriptive statistics on all four variables, namely, Awareness, Adoption, Attitude, and Adoption of the technology. With regards to the awareness of the students, the results indicate that the newly intake students are relatively aware on the existence of iGracias in their campus. Students level of awareness on iGracias are ranging from $68.8 \%$ to $86.3 \%$, with the mean of 3.11 , standard deviation of 0.71 , and overall percentage of $71.0 \%$. The details are provided on Table 2 below.

Tabel 2

\section{Awareness on iGracias}

\begin{tabular}{|c|c|c|c|c|}
\hline No & Statements & $\mathbf{M}$ & SD & $\%$ \\
\hline 1 & I am aware that our university has already implemented the iGracias & 3.45 & 0.62 & 86.3 \\
\hline 2 & I am aware that the registration of iGracias is free & 3.43 & 0.65 & 85.8 \\
\hline 3 & I am aware of the benefits of iGracias before registering & 3.22 & 0.60 & 80.5 \\
\hline 4 & I am aware that the university provides guidelines for the iGracias & 3.05 & 0.66 & 76.3 \\
\hline 5 & I am aware that the iGracias services are available 24 hours & 3.13 & 0.81 & 78.3 \\
\hline 6 & I am aware of the rules and regulations of using the iGracias & 3.01 & 0.71 & 75.3 \\
\hline 7 & I am aware that the iGracias is convenient for my academic tasks & 3.23 & 0.68 & 80.8 \\
\hline 8 & I am aware that the iGracias can be accessed by multiple platforms & 3.05 & 0.84 & 76.3 \\
\hline 9 & I am aware that the university is accountable to solve any technical problem of iGracias & 2.84 & 0.78 & 71.0 \\
\hline 10 & I am aware that the iGracias can also be accessed outside of the campus area & 2.75 & 0.79 & 68.8 \\
\hline & Total & 3.11 & 0.71 & 77.9 \\
\hline
\end{tabular}

Source: Results of data analysis

Table 3 shows the perception of the newly intake students on using the iGracias. The results indicate that their level of perception are ranging from $67.8 \%$ to $80.5 \%$ which mean that they have a relatively positive perception towards using the iGracias. This notion is reflected by the mean of 3.22 , standard deviation of 0.69 , and overall percentage of $73.8 \%$. The details can be found on the table below.

Tabel 3

\section{Perception on iGracias}

\begin{tabular}{|c|c|c|c|c|}
\hline No & Statements & $\mathbf{M}$ & SD & $\%$ \\
\hline 1 & I think that the iGracias helps improve my academic performance & 2.77 & 0.72 & 69.3 \\
\hline 2 & I think that the iGracias will trigger more virtual interaction among students & 2.97 & 0.64 & 74.3 \\
\hline 3 & $\begin{array}{l}\text { I think that the iGracias is necessary and adequate for campus information } \\
\text { dissemination }\end{array}$ & 3.22 & 0.58 & 80.5 \\
\hline 4 & I believe that the iGracias implementation would be beneficial & 3.07 & 0.62 & 76.8 \\
\hline 5 & I believe that the iGracias will keep me updated with campus current events & 2.96 & 0.73 & 74.0 \\
\hline 6 & I believe that the iGracias will make me a responsible as a user & 2.96 & 0.65 & 74.0 \\
\hline 7 & I believe that the iGracias will be better than other system in the campus & 3.16 & 0.90 & 79.0 \\
\hline 8 & I believe that the iGracias has improved my creativity & 2.71 & 0.74 & 67.8 \\
\hline 9 & I believe that the iGracias will make me keep up with my academic goals & 2.75 & 0.68 & 68.8 \\
\hline \multirow[t]{2}{*}{10} & $\begin{array}{l}\text { I believe that the university will improve the quality of the free wireless c iGracias } \\
\text { onnection in the near future }\end{array}$ & 2.98 & 0.70 & 74.5 \\
\hline & Total & 3.22 & 0.69 & 73.8 \\
\hline
\end{tabular}

Source: Results of data analysis 
With regards to the students' attitude towards the usage of iGracias, the results indicate that the students are generally have a positive attitude towards the technology. These shown by the mean of 2.86 , standard deviation of 0.80 , and overall percentage of $71.6 \%$. Specifically, the measurement of each item related to the students' attitude are ranging from $67.3 \%$ to $78.0 \%$. The details of results analysis are displayed on Table 4 below.

\section{Tabel 4}

\section{Attitude on iGracias}

\begin{tabular}{clccc}
\hline No & Statements & M & SD & \% \\
\hline 1 & I prefer to use the iGracias in hostels area rather than going to the computer labs & 3.02 & 0.97 & 75.5 \\
\hline 2 & I like to use the iGracias because it allows me to finish my work faster & 2.93 & 0.83 & 73.3 \\
\hline 3 & I like to use the iGracias because it is accessible in all places in the campus & 2.71 & 0.82 & 67.8 \\
\hline 4 & I prefer to use the iGracias because it is accessible anytime & 2.81 & 0.81 & 70.3 \\
\hline 5 & I like the iGracias because it is user friendly & 2.76 & 0.77 & 69.0 \\
\hline 6 & I like spending more time on web surfing since I installed the iGracias & 2.69 & 0.84 & 67.3 \\
\hline 7 & I prefer to use the iGracias to avoid queuing up in the administration offices & 3.12 & 0.79 & 78.0 \\
\hline 8 & I feel that the iGracias makes my study a lot easier & 2.91 & 0.80 & 72.8 \\
\hline 9 & I like the iGracias because it provides me with various features & 2.85 & 0.73 & 71.3 \\
\hline 10 & I feel more comfortable doing my task through the iGracias & 2.85 & 0.70 & 71.3 \\
\hline & Total & $\mathbf{2 . 8 6}$ & $\mathbf{0 . 8 0}$ & $\mathbf{7 1 . 6}$ \\
\hline
\end{tabular}

Source: Results of data analysis

Finally, concerning the actual technological adoption of iGracias, the results show that the newly intake students are commonly adopting the technology. These findings are derived from the descriptive analysis which reported a mean of 2.82 , standard deviation of 0.79 , and overall percentage of $70.6 \%$. A close evaluation on each item with regards to the usage of iGracias show that the level of adoption are ranging from $59.0 \%$ to $80.5 \%$. The findings indicate that eventually the newly intake students are steadily adopting and frequently using the technology. The details of each item are presented on the following table.

Tabel 5

\section{Adoption of iGracias}

\begin{tabular}{|c|c|c|c|c|}
\hline No & Statements & $\mathbf{M}$ & SD & $\%$ \\
\hline 1 & I registered for the iGracias as soon as it was introduced & 2.51 & 0.99 & 62.7 \\
\hline 2 & I found it easy to adapt to the iGracias & 2.57 & 0.84 & 64.3 \\
\hline 3 & I use the iGracias to help me achieve my academic goals & 2.74 & 0.76 & 68.5 \\
\hline 4 & I use the iGracias for academic purposes & 3.06 & 0.73 & 76.5 \\
\hline 5 & I can finish my academic task with less effort by using the iGracias & 2.81 & 0.73 & 70.3 \\
\hline 6 & I use the iGracias with responsibility & 3.01 & 0.68 & 75.3 \\
\hline 7 & I become more active in forum discussions since I used the iGracias & 2.36 & 0.79 & 59.0 \\
\hline 8 & I use the iGracias because it is free of charge & 3.22 & 0.79 & 80.5 \\
\hline 9 & I use the iGracias to have more privacy and security & 2.93 & 0.83 & 73.3 \\
\hline & I use the iGracias to save a lot of time & 3.05 & 0.76 & 76.3 \\
\hline & Total & 2.82 & 0.79 & 70.6 \\
\hline
\end{tabular}

Source: Results of data analysis 
The computed items of each variable are shown in Table 6 below. The results indicate the newly intake students are well aware of the existence of iGracias in their campus (77.9\%). Simultaneously, the students are also have positive perception $(73.8 \%)$ and attitude $(71.6 \%)$ towards the iGracias in their first few months since joining the University. Last but not least, the findings point out that the adoption rate of iGracias is relative high among the students with the overall percentage of $70.6 \%$. The summary analysis of all variables are displayed on the following table.

Tabel 6

Summary of All Variables

\begin{tabular}{clccc}
\hline No & \multicolumn{1}{c}{ Statements } & M & SD & \% \\
\hline 1 & Awareness & 3.12 & 0.71 & 77.9 \\
\hline 2 & Perception & 2.96 & 0.69 & 73.8 \\
\hline 3 & Attitude & 2.87 & 0.80 & 71.6 \\
\hline 4 & Adoption & 2.83 & 0.79 & 70.6 \\
\hline$\quad$ Source: Results of data analysis & & &
\end{tabular}

After completing and reporting the results of the descriptive statistics, the inferential statistics were applied in order to test the formulated hypothesis. To test and validate the relationships between the variables, bivariate correlations were applied. The results on table 7 indicate that there are positive and strong relationships between awareness $(r=0.644, p=0.000)$ and perception $(\mathrm{r}=0.640, \mathrm{p}=0.000)$ towards attitude on iGracias. This means students' awareness and perception on the iGracias significantly influencing their attitude towards the technology. Hence, this results support Hypothesis 1.

Additionally, the similar analysis also indicate that there is a positive and moderate relationship between attitude and adoption of the iGracias $(r=578, p=0.000)$. This means that students' attitude towards the iGracias significantly influencing their adoption of the technology. Hence, Hypothesis 2 is supported by this result. The details of bivariate correlations are displayed on the Table 7 below.

Tabel 7

Results of Bivariate Correlations

\begin{tabular}{lllccc}
\hline \multicolumn{1}{c}{ Variables } & \multicolumn{1}{c}{ Values } & AWA & PER & ATT & ADO \\
\hline \multirow{2}{*}{ Awareness } & Pearson Correlation & - & - & - & - \\
\cline { 2 - 6 } & Sig. (2-tailed) & - & - & - & - \\
\cline { 2 - 6 } Perception & $\mathrm{N}$ & $.563^{*}$ & - & - & - \\
\cline { 2 - 6 } & Pearson Correlation & .000 & - & - & - \\
\cline { 2 - 6 } & Sig. (2-tailed) & 210 & - & - & - \\
\hline \multirow{2}{*}{ Attitude } & Pearson Correlation & $.644^{*}$ & $.640^{*}$ & - & - \\
\cline { 2 - 6 } & Sig. (2-tailed) & .000 & .000 & - & - \\
\cline { 2 - 6 } & $\mathrm{N}$ & 208 & 210 & - & - \\
\hline
\end{tabular}




\begin{tabular}{lllllll}
\hline \multirow{2}{*}{ Adoption } & & & & & \\
& Pearson Correlation & $.548^{*}$ & $.558^{*}$ & $.578^{*}$ & - \\
\cline { 2 - 7 } & Sig. (2-tailed) & .000 & .000 & .000 & - \\
\cline { 2 - 7 } & $\mathrm{N}$ & 205 & 207 & 206 & - \\
\hline
\end{tabular}

*. Correlation is significant at the 0.01 level (2-tailed).

In order to test and validate the mediating effects, the partial correlations was applied accordingly. The results on Table 8 indicate that attitude towards iGracias has a mediating effect on awareness towards the adoption of the technology $(\mathrm{r}=0.556, \mathrm{p}=0.000)$. Additionally, the results also show that attitude towards iGracias also has a mediating effect on perception towards the adoption of the technology $(\mathrm{r}=0.507, \mathrm{p}=0.000)$. These means that students' awareness and perception towards the iGracias will have higher chances of leading towards its adoption when its supported by students' positive attitude towards the technology. Hence, these results support Hypothesis 3. The details are presented on Table 8 below.

Tabel 8

Results of Partial Correlations

\begin{tabular}{|c|c|c|c|c|}
\hline \multicolumn{3}{|c|}{ Controlling Variables } & \multicolumn{2}{|c|}{ Adoption } \\
\hline \multirow{6}{*}{ Attitude } & Awareness & Correlation & - & .556 \\
\hline & & Significance (2-tailed) & - & .000 \\
\hline & & $\mathrm{df}$ & - & 200 \\
\hline & Perception & Correlation & .507 & - \\
\hline & & Significance (2-tailed) & .000 & - \\
\hline & & $\mathrm{df}$ & 203 & - \\
\hline
\end{tabular}

*. Correlation is significant at the 0.01 level (2-tailed).

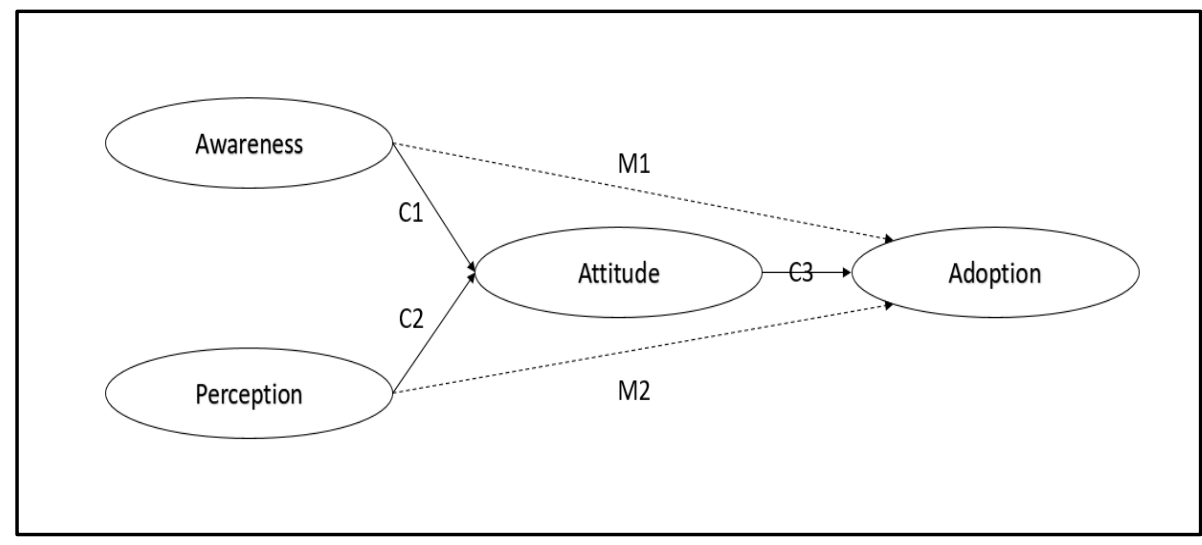

Figure 4: Validated Research Model

(Source: developed by researcher)

As the final objective of the research, a validated research has therefore been confirmed (see Figure 4 below). This model proposes that the students' awareness and perception towards the iGracias will have higher chances of leading towards its adoption when its supported by students' positive attitude towards the technology. 


\section{CONCLUSION}

This study was based on two interrelated theories, namely, the original Technology Acceptance Model (Davis, 1986) and the advanced Technology Acceptance Model (Venkatesh \& Davis, 2000), as well as reviewing the implementation of Everett Rogers' Theory of Diffusion of Innovations (1995). These theories develop a conceptual framework of technological behavior with the technology adoption as the actual output. Practically, this study aims at measuring the level of awareness, perception, and attitude towards iGracias and its impact on the newly intake students' actual adoption.

The results of the study indicate that both awareness and perception are positively and significantly related to attitude towards the iGracias. These findings confirm the assumptions of Wojtecki and Peters (2000), Reed (2001), Kearns (2004), as well as Jones and Johnson (2005). Furthermore, the analysis also point out a positive and significant relationship between attitude on iGracias towards its adoption which reflect the notion of Weick (1990). Simultaneously, the inferential statistics also suggest that attitude towards the technology has mediating effects on awareness and perception towards the adoption of the iGracias. On the summary, the findings of the study are supporting all of the formulated hypotheses.

\section{Journal:}

\section{REFERENCES}

Imran, A. I. 2016. Communication Factors Influencing Academicians' Innovative Working Behavior and Its Impact on Their Career Advancement. Jurnal Lingkar Studi Komunikasi, February Edition, Vol 2, No 1 (2016).

Lai, P. C. 2017. The Literature Review of Technology Adoption Models and Theories for the Novelty Technology. Journal of Information Systems and Technology Management, Vol. 14, No. 1, January/April, 2017. pp. 21-38.

Mun Y. Yi, Joyce D. J., Jae S. P. \& Janice C. P. 2006. Understanding information technology acceptance by individual professionals: Toward an integrative view. Information \& Management, 43, pp. 350-363.

Venkatesh, V., \& Davis, F. D. 2000. A Theoretical Extension of the Technology Acceptance Model: Four Longitudinal Field Studies. Management Science, 46 (2), 186-204.

Wojtecki, J. G., \& Peters, R.G. 2000. Communication Organizational Change: Information Technology Meets the Carbon-based Employee Unit. The 2000 Annual: Vol. 2. JosseyBass/Pfeiffer, San Francisco.

\section{Book:}

Davis, F.D. 1986. A Technology Acceptance Model for Empirically Testing New End-user Information systems: Theory and results. Massachusetts, United States: Sloan School of Management, Massachusetts Institute of Technology.

Rogers, E.M. 1995. Diffusion of Innovations. 4th ed., New York: The Free Press

Weick, K. E. 1990. Technology as Equivoque: Sensemaking in New Technologies. Goodman, Paul S. (Ed.). Technology and Organizations. San Fransico, CA: Jossy-Bass Publishers. 


\section{Thesis and Dissertation:}

Jones, S., \& Johnson, C. 2005. The Internet's Impact on College Faculty in Almobarraz, A. 2007. Perceived Attributes of Diffusion of Innovation Theory as Predictors of Internet Adoption among the Faculty Members of Imam Mohammed bin Saud University. Dissertation. University North Texas.

Reed, T. E. 2001. Relationship between Learning Style, Internet Access, and Internet Satisfaction of Students Taking Online Courses at a selected Community College. Dissertation. Northern Illinois University. 